\title{
Environmental and management drivers of alpine grassland vegetation types
}

\author{
Giovanni Argenti, ${ }^{1}$ Nicolina Staglianò, ${ }^{1}$ Edoardo Bellini, ${ }^{1}$ Alessandro Messeri, ${ }^{1}$ Stefano Targetti ${ }^{2}$ \\ ${ }^{1}$ Dipartimento di Scienze e Tecnologie Agrarie, Alimentari, Ambientali e Forestali (DAGRI), Università degli \\ Studi di Firenze; 'Dipartimento di Scienze e Tecnologie Agro-Alimentari (DISTAL), Università degli Studi \\ di Bologna, Italy
}

\begin{abstract}
Current vegetation of alpine grasslands has been shaped by the combination of natural ecological factors (such as climate, soil, topography) and human activities, mainly represented by animal grazing and agricultural practices. An assessment of these factors can explain the present composition of plant communities and help to evaluate the future development of rangeland vegetation. Nowadays, the analysis of the botanical composition of grasslands is of a major importance in order to propose appropriate management plans for the sustainable exploitation of pastoral resources and their future conservation. The main purpose of this work was to assess the relevance of ecological and management factors in alpine grasslands in an area located in eastern Italy, currently used for extensive grazing, and to describe the main factors that affect the characteristics of pasture types. To this aim, about 900 ha of alpine grasslands were surveyed in Val Visdende (northern Veneto, province of Belluno, Italy) by means of 189 linear transects. Some environmental variables (altitude, slope, aspect) and factors related to management (pastoral value, animal excreta, distance from night barns) were collected for each botanical transect. Landolt indicators were calculated in order to evaluate the ecological space occupied by each type. This assessment made it possible to identify the most relevant grassland communities (namely nutrient poor, shrub encroached, nutrient rich and humid pastures) occurring in the studied area, the effectiveness of ecological indicators to describe and to differentiate vegetation groups and the effect of animal management and ecological factors in the discrimination of grassland types.
\end{abstract}

Correspondence: Giovanni Argenti, Dipartimento di Scienze e Tecnologie Agrarie, Alimentari, Ambientali e Forestali (DAGRI), Università di Firenze, P.le delle Cascine 18 - 50144 Firenze, Italy. E-mail: giovanni.argenti@unifi.it

Key words: Pastoral value; vegetation; Landolt indicators; grasslands; grazing; stocking rate.

Received for publication: 27 January 2020.

Revision received: 5 May 2020.

Accepted for publication: 5 May 2020.

${ }^{C}$ Copyright: the Author(s), 2020

Licensee PAGEPress, Italy

Italian Journal of Agronomy 2020; 15:1600

doi:10.4081/ija.2020.1600

This article is distributed under the terms of the Creative Commons Attribution Noncommercial License (by-nc 4.0) which permits any noncommercial use, distribution, and reproduction in any medium, provided the original author(s) and source are credited.

\section{Introduction}

Alpine grasslands represent a widespread forage resource that has been designed over the centuries by environmental characteristics and management practices (Peter et al., 2004; Argenti et al., 2012) and replaced previous vegetation dominated by a variety of forests in many mountainous areas of Europe (Gellrich and Zimmerman, 2007; Primi et al., 2016). Biomass production and grazing utilization are often limited to a short period of time (Van den Pol-van Dasselaar et al., 2008) due to the physical constraints in this severe environment (Peeters, 2015). At the same time, management is usually extensive and, especially in marginal areas, characterized by undergrazing/abandonment or reduced agronomical interventions (Giustini et al., 2007; Probo et al., 2016) due to depopulation and ageing of farmers (Orlandi et al., 2016). As a consequence of this reported evolution, a general reforestation of secondary grassland can be identified that is generally preceded by encroachment by woody species (Targetti et al., 2013; Iussig et al., 2015).

Vegetation occurring on a specific area is always represented by different grassland types (Cavallero et al., 2007) and their identification is one of the most important assessment that can be conducted in pastoral research (Cavallero et al., 2002). Grassland types can be defined as plant communities characterized by the dominance of a limited number of species and the presence of a variable number of species sharing similar ecological conditions (Cavallero et al., 2007). Pastoral types differ in terms of botanical composition and, in turn, in carrying capacity (Argenti and Lombardi, 2012). Therefore, the assessment of vegetation can be also considered a tool to implement pasture planning (Pittarello et $a l ., 2019)$ and analyze the impact of specific management options on pastoral resources (Pornaro et al., 2019).

Nowadays, these resources serve as a source of forage biomass and also provide a wide range of ecosystem services (Lamarque et al., 2011; Gargano et al., 2017; Bengtsson et al., 2019), such as preservation of endangered species or habitat for wildlife, protection against erosion, maintenance of soil fertility, enhancement of carbon sequestration, landscape heterogeneity conservation (Laiolo et al., 2004; Ponzetta et al., 2010; Scotton et al., 2014; Elias and Tischew, 2016; Hao et al., 2017). Future preservation of these services will be influenced by human management (Komac et al., 2014; Rodríguez-Ortega et al., 2014), in terms of stocking rate, time and duration of utilization, employed animal species and by environmental factors, such as topography, geomorphology, soil and climate (Chamberlain et al., 2013; Dibari et al., 2016; Rojas-Downing et al., 2017).

The main aim of this work was to perform an analysis on how management and ecological factors can affect the characteristics and the distribution of various types of alpine grasslands, which in the study area were exclusively natural pastures. This kind of assessment can be performed at a landscape or local level (Orlandi 
et al., 2016). In our case, we selected to operate at the local level on a limited area represented by an internal valley in eastern Italian Alps, as an assessment at a small spatial scale is useful to detect the extreme variability in vegetation properties present in alpine pastures (Rossignol et al., 2014) and to analyze the impact of management practices and environment on vegetation (Pornaro et al., 2019). The study area is characterized by land abandonment and a remarkable reduction in animal utilization (Argenti et al., 2011). The entire valley presented a wide range of different environmental conditions due to geo-topographical variability, and a mosaic of abandoned and more intensively utilized areas. Therefore, this study allowed us to evaluate the importance of different management and physical factors on occurring grassland types.

\section{Materials and methods}

This study was conducted in Val Visdende (latitude $46.6088 \mathrm{~N}$, longitude $12.6292 \mathrm{E}$ ), a valley located in the northern part of the Veneto Region (province of Belluno), in the north-eastern part of the Italian alpine chain, near the Austrian border. Its altitude ranges from about $1600 \mathrm{~m}$ to $2300 \mathrm{~m}$ above sea level, the mean annual temperature is $2.7^{\circ} \mathrm{C}$ and the average annual rainfall is $1288 \mathrm{~mm}$. Data from a weather station in Campobon, located approximately in the middle of the studied area at an altitude of $1941 \mathrm{~m}$ asl, showed that half of the total annual rainfall occurs during the vegetation growing period (Targetti et al., 2010). The soil substrate is complex and heterogeneous and includes both shale-clay (siliceous) and calcareous-dolomite parent material (Sabatini et al., 2008). The farming system used on the studied grasslands is widely extensive and involves only grazing in summertime, despite this entire territory had a remarkable decrease of the pasture surface over the last 40 years (Targetti et al., 2010). The period of utilization for animal husbandry (mainly cattle) extends from early June to the mid-September, with some slight adaptation according to inter-annual variation of forage availability. The surface of the pasture land in the studied valley is about 900 ha, is owned by local communities (Regole) and is divided into several upland farms (malghe) (Table 1).

In the study site, a botanical survey was performed in order to assess pastoral characteristics and the distribution of the grassland types occurring in the area. The botanical composition was assessed by means of 189 linear point-quadrat transects scattered on the entire area according to Daget and Poissonet method (1971). Each transect was geographically localized by means of a GPS device and marked on 1:10,000 technical maps (Veneto Cartographic Service). Along the transects, each species touching a steel needle was recorded obtaining the Specific Frequency $\left(\mathrm{SF}_{\mathrm{i}}\right)$ of the $i$-species, i.e. the number of times that a given species was encountered along the line (Argenti and Lombardi, 2012). The number of species recorded along a transect represented the floristic richness (Pornaro et al., 2019). The species nomenclature was reported according to Pignatti (1982).

Based on $\mathrm{SF}_{\mathrm{i}}$, the Species Contribution $\left(\mathrm{SC}_{\mathrm{i}}\right)$ for each species to the botanical composition of the pasture was determined as:

$$
\mathrm{SC}_{i}=\frac{\mathrm{SF}_{i}}{\sum \mathrm{SF}_{i}} \times 100
$$

where $\mathrm{SC}_{\mathrm{i}}$ is an estimation of the percentage occurrence of a species inside the canopy (Probo et al., 2013).

For every botanical transect, the Pastoral Value (PV, Daget and Poissonet, 1972) was obtained using the following formula:

$$
\mathrm{PV}=\frac{\sum\left(\mathrm{SC}_{\mathrm{i}} \times \mathrm{SI}_{\mathrm{i}}\right)}{5} \times 100
$$

where $\mathrm{SI}_{\mathrm{i}}$ is a synthetic index (ranging from 0 to 5) assigned to a given species to summarize its forage value (Cavallero et al., 2002). PV values ranged from 0 to 100 and were used to assess the global forage potential of this pastoral area and, by means of a transformation coefficient, its carrying capacity (Cavallero et al., 2007).

The importance of some environmental factors was assessed using Landolt indicators, originally proposed for Swiss flora (Landolt, 1977; Landolt et al., 2010), but later widely applied in several Italian pastoral environments (e.g. Lonati, 2005; Targetti et al., 2010; Gusmeroli et al., 2013; Orlandi et al., 2016; Pornaro et al., 2019). A value on a scale ranging between 1 and 5 was given to each plant species taking into account its sensitivity to a specific environmental factor. For each transect, the weighted averages (using SC of each species as weight) of the Landolt indicators (Table 2) recognized as being most relevant for the description of the grassland characteristics according to previous research were evaluated (Argenti and Lombardi, 2012; Gusmeroli et al., 2013; Pornaro et al., 2019). For each identified vegetation type, the average values of selected Landolt indicators were graphically represented by means of ecograms, namely radar charts with six axes, one for each Landolt index (Domina et al., 2018).

The topographical characteristics (elevation, slope, aspect) were extracted from technical maps for each sample area. South and west aspects were arranged according to Chang et al. (2004). Distances from each transect to the nearest night barn were calculated as a potential factor affecting vegetation utilization by animals. The percentage of ground covered by excreta and rocks and the proportion of bare soil were both assessed simultaneously for the vegetation transects by means of a visual estimation for each botanical analysis.

Table 1. Characteristics of summer farms of the Val Visdende area.

\begin{tabular}{lccccc} 
Summer farm & Surface (ha) & Altitudinal range (m asl) & Average slope (\%) & Main aspect & Sulbstrate \\
Londo & 146 & $1610-2210$ & 37 & SE & Siliceous/calcareous \\
Dignas & 90 & $1600-2150$ & 32 & SE & Calcareous/siliceous \\
\hline Antola & 69 & $1850-2280$ & 20 & SE & Siliceous \\
Campobon & 268 & $1790-2330$ & 39 & S & Siliceous/calcareous \\
\hline Cecido & 137 & $1940-2300$ & 27 & SW & Siliceous \\
Manzon & 181 & $1850-2250$ & 25 & S & Siliceous \\
\hline
\end{tabular}


In addition, direct interviews to farmers and staff of local public boards and municipalities allowed us to obtain the real average number of animals grazing in the summer season for each summer farm. These animal data were transformed in Livestock Units (LUs) according to Allen et al. (2011) to standardize the presence of different animal species in the herd or different age classes of individuals inside the same species.

The data from every botanical transect were organized in a species $\times$ transect matrix. All transects were grouped by means of a hierarchical cluster analysis in order to identify the main grasslands types occurring in the area (Borchardt et al., 2011). BrayCurtis dissimilarity coefficient was used as a measure of distance among clusters and Ward's method was used to investigate agglomeration (Argenti and Lombardi, 2012). The principal components analysis (PCA), after a Z-score standardization (Leps and Šmilauer, 2003), was adopted to identify the ecological or management factors with the highest influence on the distribution of pasture types (Dibari et al., 2016). Anova was performed among identified types to test differences in specific parameters. All statistical analyses were performed using SPSS Statistics for Windows package release 25 (IBM, 2017).

\section{Results}

The assessment of the pastoral area allowed us to evaluate the level of pasture utilization (Table 3). The pastoral values ranged from low (12) to moderate (20) and were used to derive the carrying capacity for the whole grazing season in terms of LUs. The actual number of LUs reared in each farm was used to evaluate the utilization percentage as a ratio between the real stocking rate and the carrying capacity. Our results showed a clear and remarkable underutilization of the whole area, with a maximum utilization rate of about $20 \%$ and the lowest value of the carrying capacity at $4 \%$.

A cluster analysis was performed to evaluate the agglomeration of the 189 botanical transects that were grouped into four clusters (Figure 1), which corresponded to four grassland types with remarkable differences in terms of environmental conditions and vegetation characteristics (Table 4). Group 1 (nutrient poor), occurring on 291 ha, was represented by pastures in low fertility soils, mainly dominated by matgrass (Nardus stricta, 10.6 as average SC) and with a significance presence of high-altitude species, such as Festuca gr. rubra $(\mathrm{SC}=8.2)$, Leontodon helveticus ( $\mathrm{SC}=6.5)$, Geum montanum $(\mathrm{SC}=5.4)$ and Homogyne alpina $(\mathrm{SC}=5.1)$. The average pastoral value of this type was rather low (13.9) and its average altitude was over $2000 \mathrm{~m}$ asl. Group 2 (shrubs encroached) was represented by grasslands with a high percentage of woody species cover (more than 30\%), mainly belonging to Ericaceae family; Calluna vulgaris ( $\mathrm{SC}=9.1$ ), Vaccinium myrtillus $(\mathrm{SC}=7.5)$ and Rhododendron ferrugineum (6.8) were the main shrubs of this type, while Nardus stricta

Table 2. Landolt indicators used in the study.

\begin{tabular}{ll} 
Index & Description \\
$\mathrm{F}$ & Soil moisture \\
$\mathrm{R}$ & Soil reaction $(\mathrm{pH})$ \\
\hline $\mathrm{N}$ & Level of nutrients in the soil (especially $\mathrm{N})$ \\
$\mathrm{H}$ & Humus content \\
\hline $\mathrm{L}$ & Radiation needs of species \\
$\mathrm{T}$ & Temperature needs of species \\
\hline
\end{tabular}

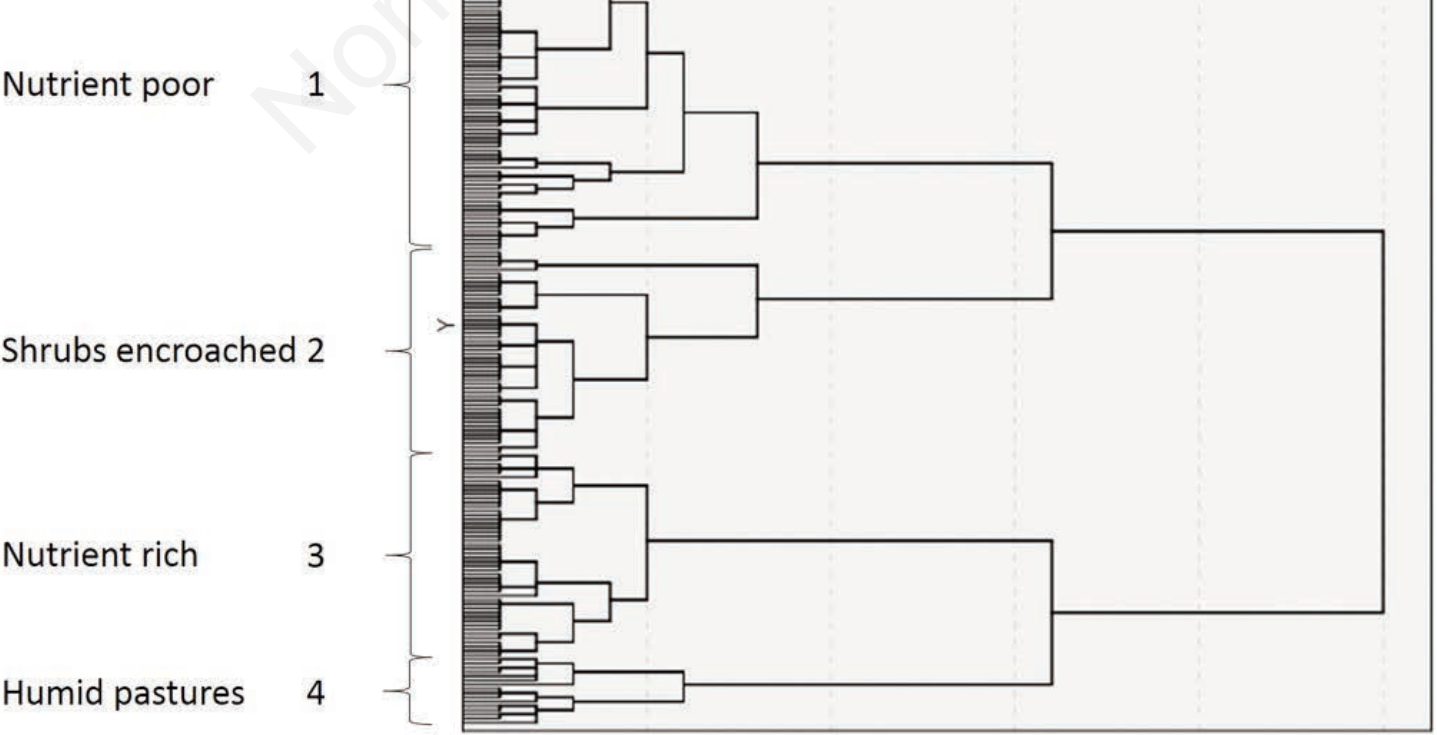

Figure 1. Cluster analysis of 189 botanical samples for identification of grassland types. 
( $\mathrm{SC}=6.8$ ) was the main herbaceous species, followed by species belonging to Luzula and Carex genera. This group was the most widespread in the study area (320 ha), at an average altitude comparable to that of group 1 and in sites with an average slope which was significantly higher than other pasture types. Its pastoral value was the lowest recorded among the four groups (9.5), as almost all recorded woody species were not palatable and therefore had a Specific Index equal to 0 . Moreover, in some areas accessibility of livestock was affected by a high density of shrubs. Group 3 (nutrient rich) was represented by pastures in soils with good fertility and was the most utilized by grazing animals. This grassland type, located at the lowest altitudes, was very often in the surroundings of night barns (on 179 ha), it was maintained by animal utilization that guaranteed an adequate return of animal excreta to the soil (more than $5 \%$ as ground cover). The main species is Festuca gr. rubra $(\mathrm{SC}=10.8)$, followed by Alchemilla gr. vulgaris $(\mathrm{SC}=5.5)$, Carex sempervirens $(\mathrm{SC}=4.9)$ and Trifolium repens $(\mathrm{SC}=4.7)$. This group is characterized by a relatively high forage quality $(P V=22.4)$ and the highest level of species richness per transect. Group 4 (humid pastures) consisted largely of species typical of high-humidity soils, such as the most widespread Deschampsia cespitosa $(\mathrm{SC}=18.8)$ and Alchemilla gr. vulgaris $(\mathrm{SC}=11.2)$, and by palatable species, like Phleum alpinum $(\mathrm{SC}=15.0)$ and Festuca gr. rubra $(\mathrm{SC}=8.5)$. This type was the less represented in the study area (101 ha) and was characterized by low species richness, but it presented the best forage quality (PV equal to 26.5).

Group 1 and 2 presented very similar ecograms according to weighted Landolt indicators (Figure 2), as they occupied almost the same ecological space. Both groups were distributed in areas with low $\mathrm{pH}$ (mainly acid), reduced fertility (low $\mathrm{N}$ values) and a high level of humus accumulation (likely due to low decomposition rates of the litter). These variables differentiate these types from others. Groups 3 and 4, on the contrary, were mainly characterized by higher soil fertility, with neutral reaction. Group 4 presented the highest average humidity (F, values over 3 ). The $\mathrm{T}$ indicator related to temperature was almost the same for all the studied vegetation types (with exception of the nutrient-poor group).

The Principal Components Analysis allowed us to describe the ecological and management factors that were mainly able to discriminate groups along the first three axes accounting for $53.6 \%$ of the total variance and to outline the differences between the identified grassland types (Table 5). The adequacy of the analysis was assessed by the Kaiser-Meyer-Olkin measure (KMO, equal to 0.610 in our case) and by the Bartlett's test of sphericity $(\mathrm{P}<0.0001)$. The PCA (Figure 3) shows a clear differentiation between types 1, 3 and 4 (herbaceous dominated) vs. type 2 (shrub dominated). In particular, considering the first axis, humus, nutrients and $\mathrm{pH}$ played a major role in the characterization of type 2 . Actually, types 1 and 2 were correlated along the first axis to humus accumulation and acid substrates, and a clear discrimination was produced by a high distance from night barns and increasing slope (especially for type 2). On the contrary, types 3 and 4 were distributed mainly on the left side of the first axis and were highly correlated to more alkaline $\mathrm{pH}$ and to increasing fertility in the soil. Along the second axis, the different types were mainly discriminated by temperature ( $\mathrm{T}$ values, inversely correlated to elevation), presence of species in relation to the light ( $\mathrm{L}$ values, which was lower in shrubs encroached grasslands), elevation and distance from night barns, which was especially important to discriminate type 1 represented by pastures on low-fertility soils. Other factors, such as the proportion of ground covered by animal excreta or rocks or bare soil, proved to have a limited power of discrimination among types.

\section{Discussion}

As already clearly pointed out by previous researches in alpine environments (Ziliotto et al., 2004), the analyses of botanical composition and pasture quality performed by means of the pastoral value helped to assess forage potential production and the nutritional value, which is also related to the quality of the derived products (Bovolenta et al., 2012). The identification of different pasture types is not only an important tool to describe pastoral areas (Argenti and Lombardi, 2012), but it is also very useful in

Table 3. Pastoral characteristics of the assessed summer farms.

\begin{tabular}{lccccc} 
Summer farm & Average PV \pm S.E. & Seasonal carrying capacity (LUs) & Actual stocking rate (LUs) & Utilization rate (\%) \\
Londo & $20 \pm 2.1$ & 171 & 34 & 20 \\
Dignas & $14 \pm 1.7$ & 72 & 12 & 12 \\
\hline Antola & $15 \pm 1.0$ & 61 & 25 & 20 \\
Campobon & $13 \pm 1.1$ & 190 & 4 & 13 \\
Cecido & $12 \pm 1.0$ & 100 & 18 & 14 \\
Manzon & $12 \pm 1.2$ & 131 & & 4 \\
\hline
\end{tabular}

LU, livestock unit. According to Allen et al., 2011.

Table 4. Main characteristics of identified grassland types.

\begin{tabular}{|c|c|c|c|c|c|c|}
\hline Grassland type & N. of transects & Area (ha) & Pastoral value & Species richness & Average altitude ( $\mathrm{m}$ asl) & Average slope (\%) \\
\hline 1. Nutrient poor & 77 & 291 & $13.9^{c} \pm 0.5$ & $20.3^{\mathrm{b}} \pm 0.6$ & $2081^{\mathrm{a}} \pm 16.4$ & $25.8^{\mathrm{b}} \pm 2.7$ \\
\hline 2. Shrubs encroached & 48 & 320 & $9.5^{\mathrm{d}} \pm 0.6$ & $22.1^{\mathrm{b}} \pm 0.7$ & $2016^{\mathrm{a}} \pm 13.0$ & $50.3^{\mathrm{a}} \pm 4.7$ \\
\hline 3. Nutrient rich & 48 & 179 & $22.4^{\mathrm{b}} \pm 2.1$ & $27.9^{\mathrm{a}} \pm 1.2$ & $1892^{\mathrm{b}} \pm 25.2$ & $26.9^{\mathrm{b}} \pm 3.6$ \\
\hline 4. Humid pastures & 16 & 101 & $26.5^{\mathrm{a}} \pm 2.2$ & $10.9^{c} \pm 0.9$ & $1913^{b} \pm 22.2$ & $26.9^{\mathrm{b}} \pm 8.4$ \\
\hline Total area & 189 & 891 & 15.2 & 21.9 & 2002 & 30.2 \\
\hline
\end{tabular}

Data are reported as average \pm S.E., values with the same letter are not significantly different for $\mathrm{P}<0.05$. 
order to assess their carrying capacity (Cavallero et al., 2007). In our site, carrying capacity data compared with the real stocking rate highlighted a remarkable reduction of animal pressure on the studied resources and the consequent effect on vegetation. This process was similar to that reported by other studies carried-out in the alpine chain or in other mountain areas in Europe (Camacho et al., 2008; Álvarez-Martínez et al., 2016; Gianguzzi et al., 2018). The underutilization, which is recognized to affect grasslands characteristics and their botanical composition (Orlandi et al., 2016), emerged as the most threatening factor for these resources and their conservation. Therefore, only a rational management approach based on an accurate planning aimed at achieving balance between the actual stocking rate and the carrying capacity could counterbalance their ongoing evolution (Pittarello et al., 2019). However, the stocking rate adjustment should be coupled with the implementation of a proper grazing technique, such as rotational grazing, in order to produce an actual improvement in forage production and in the grassland botanical composition (Perotti et al., 2018).

The most frequent pasture types identified in our study were dominated by matgrass (group 1) or highly encroached by different shrub species, mainly belonging to Ericaceae (group 2). This occurrence is nowadays very common in the Alps and many studies were focused on the development of poor rangelands as an
Table 5. Variance explained and coefficients of the first three components after PCA. Only coefficients $>|0.400|$ are shown.

\begin{tabular}{lccc} 
& \multicolumn{3}{c}{ Components } \\
& 1 & 2 & 3 \\
Percentage of explained variance (\%) & 22.1 & 17.3 & 14.2 \\
Cumulative variance & 22.1 & 39.4 & 53.6 \\
\hline $\mathrm{F}$ & & & 0.493 \\
$\mathrm{R}$ & -0.860 & & \\
$\mathrm{~N}$ & -0.836 & & \\
$\mathrm{H}$ & 0.888 & & \\
\hline $\mathrm{L}$ & -0.428 & -0.760 & \\
$\mathrm{~T}$ & & 0.837 & \\
\hline Rock cover & & & \\
Excreta & & & \\
\hline Bare soil & & & \\
Elevation & 0.436 & -0.654 & \\
\hline Slope & 0.444 & & \\
Southness & & & 0.891 \\
\hline Westness & & & \\
Distance from night barn & & -0.595 \\
\hline
\end{tabular}

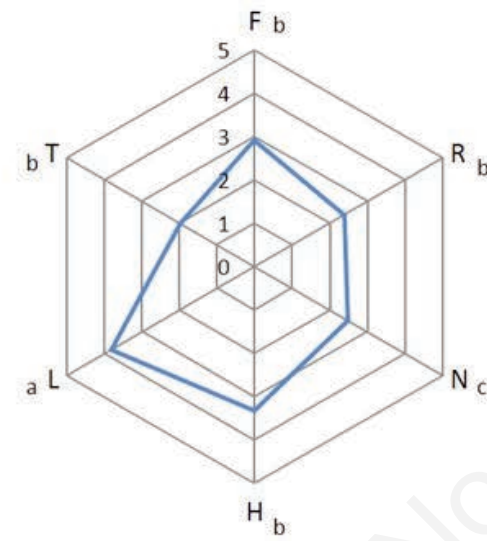

1) Nutrient poor

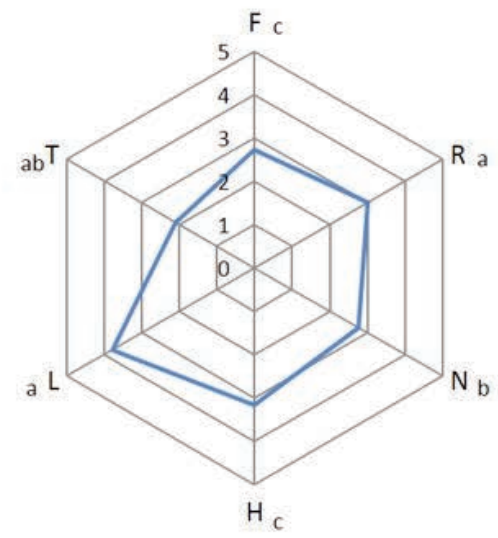

3) Nutrient rich
Figure 2. Ecodiagrams for Landolt indexes for identified grassland types. Values of indicators with the same letter are not significantly different for $\mathbf{P}<0.05$. 
effect due to land abandonment or undergrazing (e.g. Erschbamer et al., 2003), which caused changes in soil chemical properties (Urbina et al., 2020). This condition is favourable to Nardus stric$t a$, an oligotrophic low-forage quality species, which can vegetate abundantly in low-fertility areas (Güsewell et al., 2005). Therefore, this species is considered as an indicator of underutilization of pastures in comparison to their carrying capacity (Cavallero et al., 2002). This, in turn, can be considered a potential threatening factor for floristic diversity as, in many similar contexts, grazing reduction or land abandonment were acknowledged as one of the main driving factors, which can lead, in the mediumlong term, to a reduction in plant species richness and the disappearance of some species typical of semi-natural grasslands (e.g. Fischer and Wipf, 2002; Guardiola et al., 2004; Peeters, 2009). This is consistent also with our findings, comparing group 1 and group 3 in terms of species richness.

The use of Landolt indicators, or similar indexes, such as those proposed by Ellenberg (1988), represented an efficient tool to detect the importance of different environmental factors to describe the identified plant communities (Pignatti et al., 2005). In this way, it was possible to outline briefly the ecological space occupied by each vegetation type (Lonati, 2005), and consequently to compare different grassland types in order to identify the most important physical determinants which can be used to discriminate among the different groups (Pornaro et al., 2019). The indicators which differed the most among types were those concerning soil nutrients $(\mathrm{N})$ and humus $(\mathrm{H})$. This evolution can be considered as an indirect consequence of limited utilization and decreased stocking rate according to Perotti et al. (2018). Especially, nutrient enrichment of the soil by grazing animals was acknowledged as a key factor to produce remarkable changes in botanical composition and biomass production in grasslands (Augustine and Frank, 2001). Previous research has already highlighted the evident rela- tionships between pasture types and the $\mathrm{N}$ indicator observed along a gradient (Targetti et al., 2010). Ecograms did not only allow the description of the present ecological space occupied by a given type, but they are also a tool to hypothesize various dynamics and transitions among types, especially in relation to types 1 and 2, as previously acknowledged on the basis of a state-and-transition approach (Bestelmeyer et al., 2009; Targetti et al., 2010). At the same time, groups 3 and 4 shared almost the same ecological space. In this respect, the indicators relate to $\mathrm{pH}$ and soil nutrients appeared to be the most effective in discriminating them from the others.

At the same time, other features were acknowledged by the PCA to be of extreme relevance for the assessment of grassland types, such as slope and distance from the barns. These topographical factors can be considered as drivers of potential utilization of pastures, taking into account their effects on livestock accessibility (Orlandi et al., 2016). The slope is considered one of the most important factors which is negatively correlated to the grazing activity (Homburger et al., 2015). Hence, in many alpine pastures, especially characterized by a limited number of grazing animals, sites on steep slopes are the first to be abandoned and to experience a reduced presence of animals (Maurer et al., 2006). Consequently, these areas are remarkably susceptible to shrub encroachment and natural reforestation. In this respect, the results of our study were consistent with previous findings in alpine pastures (Tasser et al., 2007). At the same time, also the distance from barns represented a factor that discriminated different vegetation types, often showing a negative correlation with forage quality, as the areas closer to the barns are grazed more intensely and where animal dung is remarkably concentrated (Sabatini et al., 2008). In our study, such nutrient-rich areas showed a higher pastoral value than those located in more marginal areas, as reported also by several researchers (Skarpe and Hester, 2008; Parolo et al., 2011; Pornaro et al., 2019).

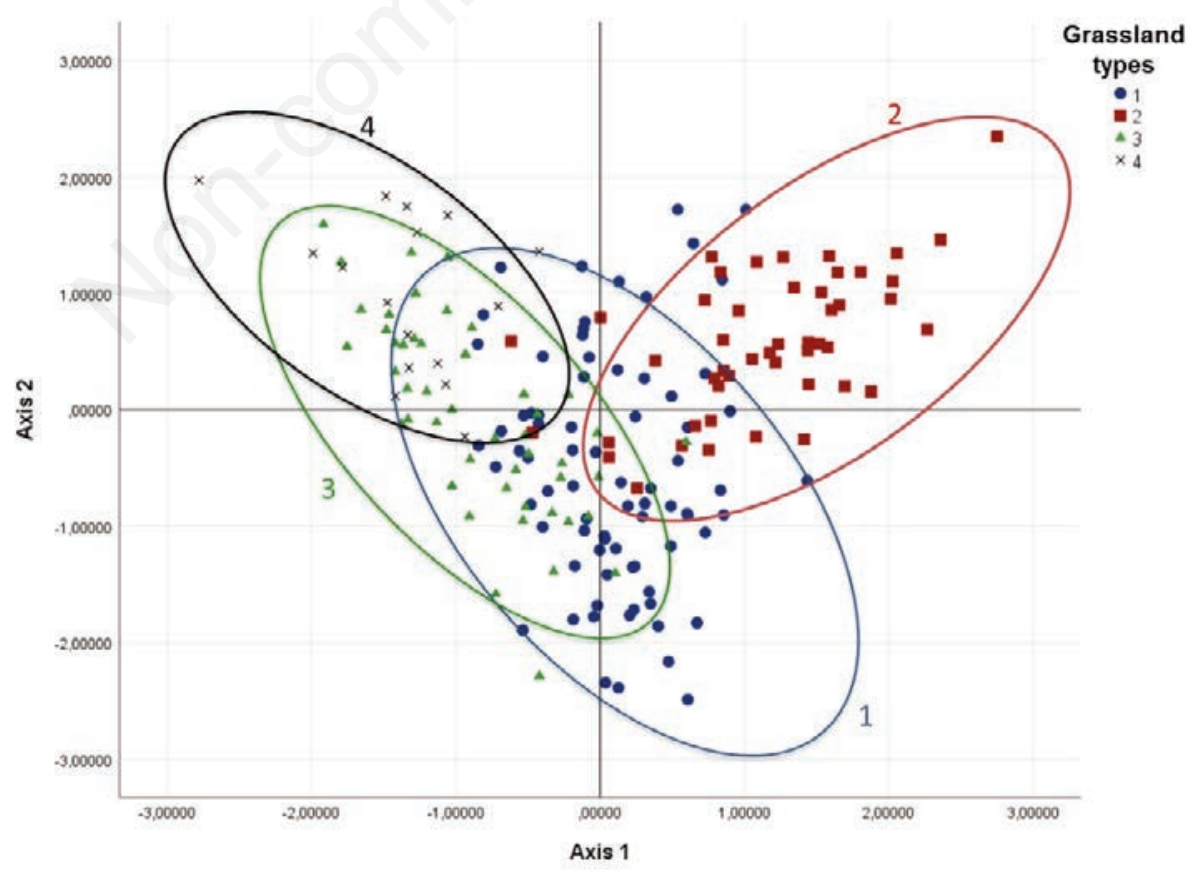

Figure 3. Principal component analysis: position of each transect (189 dots in total) on the first two axes $(39.4 \%$ of the total variance explained) and their allocation to identified grassland types. 
On the contrary, the portions of pastures located at the external border of the areas were generally characterized by the presence of oligotrophic species, often of reduced forage interest, and by a remarkable density of shrubs and woody species, as already observed by Velev and Apostolova (2008).

\section{Conclusions}

The characterisation of alpine grasslands in the studied area clearly highlighted the variability of the investigated resources (in terms of botanical composition and forage quality), the possibility of identifying relations between this variability and some specific features, such as ecological factors (slope, pedological characteristics, fertility of soil) and management factors (distance from barns) as well as the possibility of using synthetic indexes, such as Landolt indicators, to define specific environmental traits. From the analysis of these factors it was possible to hypothesize the dynamics of grassland vegetation types and to infer the basic principle for sustainable management, which is the key to conserve efficiently these resources. However, the prevalence of negative aspects, such as underutilization, irregular animal spatial distribution and use of inappropriate animal species, can result into a degradation of these areas with an increase of species of low grazing interest, such as matgrass or shrubs. The proposed approach provided evidence of the possibility of parameterizing environmental features by means of simple indicators to assess the most important factors influencing the different pasture types and to understand the evolution of vegetation depending on complex and hard-to-measure activities, such as grazing. In this context, the depiction of the dynamics among the grasslands types by means of synthetic indicators applied to a wide dataset of botanical samples is one of the most important outputs of our research. Our results highlighted also that an appropriate management approach can make it possible to drive remarkably the grassland botanical composition toward types of high forage quality.

Our results confirm the trend showing an underutilization of this sector of the Alps and its consequences in terms of pasture encroachment by shrubs. Beside the socio-environmental problems related to this phenomenon (e.g. landscape aesthetic loss, biodiversity reduction), another topic for discussion is the need for designing grazing management after an accurate assessment of the grassland carrying capacity and using grazing techniques that can effectively contribute to preserve pastoral resources. The incentives for maintaining grazing animals in the uplands are useful and the agricultural policies for mountain and/or marginal areas should not only take into account the number of animals, but also grazing management techniques and production-related parameters. Indeed, the increase of the stocking rate can be inefficient or even negative if not coupled with appropriate grazing techniques to achieve a balanced spatial distribution of animals to avoid dung concentration in the flat and easily accessible areas. In some cases, facilitating the natural vegetation dynamics in the steepest and less accessible areas could be a potential strategy to consider, however it is necessary to perform a careful analysis of the ecosystem services linked to these resources, which should go beyond mere forage production.

\section{Highlights}

This research work led to proper identification of the different types of grassland occurring in an alpine study area

The importance of main management and ecological factors to discriminate different types of pasture was assessed

Landolt indicators are an efficient and synthetic tool to describe the relationships between environmental factors and alpine plant communities

The information collected on the interaction among different types of grassland can support activities aimed at a sustainable management and conservation of these alpine herbaceous resources.

\section{References}

Allen VG, Batello C, Berretta EJ, Hodgson J, Kothmann M, Li X, McIvor J, Milne J, Morris C, Peeters A, Sanderson M, 2011. An international terminology for grazing lands and grazing animals. Grass Forage Sci. 66:2-28.

Álvarez-Martínez J, Gómez-Villar A, Lasanta T, 2016. The use of goats grazing to restore pastures invaded by shrubs and avoid desertification: a preliminary case study in the Spanish Cantabrian Mountains. Land Degrad. Develop. 27:3-13.

Argenti G, Bottai L, Chiesi M, Maselli F, Staglianò N, Targetti S, 2011. Analisi e valutazione di pascoli montani attraverso l'integrazione di dati multispettrali e ausiliari. Riv. Ital. Telerilevam. 43:45-57.

Argenti G, Cervasio F, Ponzetta MP, 2012. Control of bracken (Pteridium aquilinum) and feeding preferences in pastures grazed by wild ungulates in an area of the Northern Apennines (Italy). Ital. J. Anim. Sci. 11:336-41.

Argenti G, Lombardi G, 2012. The pasture-type approach for mountain pasture description and management. Ital. J. Agron. 7:293-9.

Augustine DJ, Frank DA, 2001. Effects of migratory grazers on spatial heterogeneity of soil nitrogen properties in a grassland ecosystem. Ecology 82:3149-62.

Bengtsson J, Bullock JM, Egoh B, Everson C, Everson T, O'Connor T, O'Farrell PJ, Smith HG, Lindborg R, 2019. Grasslands - more important for ecosystem services than you might think. Ecosphere 10:e02582.

Bestelmeyer BT, Tugel AJ, Peacock GL, Robinett DG, Shaver PL, Brown JR, Herrick JE, Sanchez H, Havstad KM, 2009. Stateand-transition models for heterogeneous landscapes: a strategy for development and application. Rangel. Ecol. Manag. 62:1-15.

Borchardt P, Schickhoff U, Scheitweiler S, Kulikov M, 2011. Mountain pastures and grasslands in the SW Tien Shan, Kyrgyzstan - Floristic patterns, environmental gradients, phytogeography, and grazing impact. J. Mt. Sci. 8:363-73.

Bovolenta S, Spanghero M, Dovier S, Orlandi D, Clementel F, 2012. Chemical composition and net energy content of alpine pasture species during the grazing season. Anim. Feed Sci. Tech. 146:178-91.

Camacho O, Dobremez L, Capillon A, 2008. Shrub encroachment in pastures in the Alps. J. Alp. Res. 96:89-100.

Cavallero A, Rivoira G, Talamucci P, 2002. Pascoli. In: R. Baldoni and L. Giardini (eds.) Coltivazioni erbacee. Foraggere e tappeti erbosi. Patron Editore, Bologna, Italy, pp 239-94.

Cavallero A, Aceto P, Gorlier A, Lombadi G, Lonati M, Martinasso B, Tagliatori C, 2007. I tipi pastorali delle Alpi piemontesi. Alberto Perdisa Editore, Bologna, Italy.

Chamberlain DE, Negro M, Caprio E, Rolando A, 2013. Assessing the sensitivity of alpine birds to potential future changes in habitat and climate to inform management strategies. Biol. Conserv. 167:127-35. 
Chang C-R, Lee P-F, Bai M-L, Lin T-T, 2004. Predicting the geographical distribution of plant communities in complex terrain - a case study in Fushian Experimental Forest, northeastern Taiwan. Ecography 27:577-88.

Daget P, Poissonet J, 1971. Une méthode d'analyse phytologique des prairies. Critères d'application. Ann. Agron. 22:5-41.

Daget P, Poissonet J, 1972. Un procède d'estimation de la valeur pastorale des pâturages. Fourrages 49:31-40.

Dibari C, Bindi M, Moriondo M, Staglianò N, Targetti S, Argenti $G, 2016$. Spatial data integration for the environmental characterization of pasture macro-types in the Italian Alps. Grass Forage Sci. 71:219-34.

Domina G, Galasso G, Bartolucci F, Guarino R, 2018. Ellenberg Indicator Values for the vascular flora alien to Italy. Fl. Medit. 28:53-61.

Elias D, Tischew S, 2016. Goat pasturing-A biological solution to counteract shrub encroachment on abandoned dry grasslands in Central Europe? Agric. Ecosys. Environ. 234:98-106.

Ellenberg H, 1988. Vegetation ecology of central Europe. Cambridge University Press, Cambridge, UK.

Erschbamer B, Virtanen R, Nagy L, 2003. The impact of vertebrate grazers on vegetation in European high mountains. In: L. Nagy, G. Grabherr, C. Körner, D.B.A. Thompson (eds) Alpine biodiversity in Europe. Springer, Berlin/Heidelberg, Germany, pp 377-395.

Fischer M, Wipf S, 2002. Effect of low-intensity grazing on the species-rich vegetation of traditionally mown subalpine meadows. Biol. Conserv. 104:1-11.

Gargano D, Aiello S, Abeli T, Schettino A, Bernardo L, 2017. Monitoring biodiversity patterns in three Mediterranean mountain pastures in the Pollino National Park (S-Italy). Plant Sociol. 54:51-9.

Gellrich M, Zimmermann N, 2007. Agricultural land abandonment and natural forest re-growth in the Swiss mountains: a spatially explicit economic analysis. Agric. Ecosyst. Environ. 118:93-108.

Gianguzzi L, Caldarella O, Di Pietro R, 2018. A phytosociological analysis of the Brachypodium rupestre (Host) Roem. \& Schult. communities of Sicily. Plant Sociol. 55:65-88.

Giustini L, Acciaioli A, Argenti G, 2007. Apparent balance of nitrogen and phosphorus in dairy farms in Mugello (Italy). Ital. J. Anim. Sci. 6:175-85.

Guardiola M, De Bello F, Taull M, Sebastià MT, 2004. Spatio-temporal changes in structural patterns in subalpine grasslands under different environmental conditions and management regimes. In: A. Lúscher, B. Jeangros, W. Kessler, O. Huguenin, M. Lobsiger, N. Millar, D. Suter (Eds). Proc. 20th Gen. Meet. European Grassland Federation, Luzern, Switzerland, 296-298.

Gusmeroli F, Della Marianna G, Fava F, Monteiro A, Bocchi S, Parolo G, 2013. Effects of ecological, landscape and management factors on plant species composition, biodiversity and forage value in Alpine meadows. Grass Forage Sci. 68:437-47.

Güsewell S, Jewell PL, Edwards PJ, 2005. Effects of heterogeneous habitat use by cattle on nutrient availability and litter decomposition in soils of an alpine pasture. Plant Soil, 268:135-49.

Hao R, Yu D, Liu Y, Liu Y, Qiao J, Wang X, Du J, 2017. Impacts of changes in climate and landscape pattern on ecosystem services. Sci. Total. Environ. 579:718-28.

Homburger H, Lüscher A, Scherer-Lorenzen M, Schneider MK, 2015. Patterns of livestock activity on heterogeneous subalpine pastures reveal distinct responses to spatial autocorrelation, environment and management. Movement. Ecol. 3:1-15.

IBM, 2017. IBM SPSS Statistics for Windows, Version 25.0.
Armonk, NY: IBM Corp.

Iussig G, Renna M, Gorlier A, Lonati M, Lussiana C, Battaglini LM, Lombardi G, 2015. Browsing ratio, species intake, and milk fatty acid composition of goats foraging on alpine open grassland and grazable forestland. Small Ruminant Res. 132:12-24

Komac B, Domènech M, Fanlo R, 2014. Effects of grazing on plant species diversity and pasture quality in subalpine grasslands in the eastern Pyrenees (Andorra): Implications for conservation. J. Nat. Cons. 22:247-55.

Landolt E, 1977. Ökologische Zeigerwerte zur Schweizer Flora. Veröffentlichtes Geobotanisches Institute ETH Stiftung Rübel, Zürich, Switzerland.

Landolt E, Bäumler B, Erhardt A, Hegg O, Klötzli F, Lämmler W, Nobis M, Rudmann-Maurer K, Schweingruber FH, Theurillat J-P, Urmi E, Vust M, Wohlgemuth T, 2010. Flora Indicativa: ecological indicator values and biological attributes of the Flora of Switzerland and the Alps. Haupt Verlag, Bern.

Lamarque P, Tappeiner U, Turner C, Steinbacher M, Bardgett RD, Szukics U, Schermer M, Lavorel S, 2011. Stakeholder perceptions of grassland ecosystem services in relation to knowledge on soil fertility and biodiversity. Reg. Environ. Change 11:791-804.

Leps J, Šmilauer P, 2003. Multivariate analysis of ecological data using CANOCO. University Press UK, Cambridge.

Lonati M, 2005. Analisi di gradienti ecologici in formazioni pascolive mediante gli indici di Landolt: un esempio in Valle Maira. Ital. Forest. Mont. 5:629-40.

Maurer K, Weyand A, Fischer M, Stöcklin J, 2006. Old cultural traditions, in addition to land use and topography, are shaping plant diversity of grasslands in the Alps. Biol. Conserv. 130:438-46.

Orlandi S, Probo M, Sitzia T, Trentanovi G, Garbarino M, Lombardi G, Lonati M, 2016. Environmental and land use determinants of grassland patch diversity in the western and eastern Alps under agro-pastoral abandonment. Biodivers. Conserv. 25:275-93.

Parolo G, Abeli T, Gusmeroli F, Rossi G, 2011. Large-scale heterogeneous cattle grazing affects plant diversity and forage value of Alpine species-rich Nardus pastures. Grass Forage Sci. 66:541-50.

Peeters A, 2009. Importance, evolution, environmental impact and future challenges of grasslands and grassland-based systems in Europe. Grassl. Sci. 55:113-25.

Peeters A, 2015. Environmental impacts and future challenges of grasslands and grassland-based livestock production systems in Europe. In: P.K. Ghosh, S.K. Mahanta, J.B. Singh, P.S. Pathak (eds) Grasslands: A Global Resource Perspective. Army Printing Press, Lucknow, India, pp 365-390.

Perotti E, Probo M, Pittarello M, Lonati M, Lombardi G, 2018. A 5-year rotational grazing changes the botanical composition of sub-alpine and alpine grasslands. Appl. Veg. Sci. 21:647-57.

Peter M, Nyfeler D, Jeanneret P, Edwards PJ, Troxler J, Lüscher A, 2004. Botanical composition of grassland in the Alps as an indicator for changes in management. In Land use systems in grassland dominated regions. In: A. Lúscher, B. Jeangros, W. Kessler, O. Huguenin, M. Lobsiger, N. Millar, D. Suter (eds). Proc. 20th Gen. Meet. European Grassland Federation, Luzern, Switzerland, 9:299-301.

Pignatti S, 1982. Flora d'Italia. ed. Edagricole, Bologna, Italy.

Pignatti S, Menegoni P, Pietrosanti S, 2005. Bioindicazione attraverso le piante vascolari. Valori di indicazione secondo Ellenberg per le piante della flora d'Italia. Braun Blanquetia 39:1-97. 
Pittarello M, Probo M, Perotti E, Lonati M, Lombardi G, Ravetto Enri S, 2019. Grazing Management Plans improve pasture selection by cattle and forage quality in sub-alpine and alpine grasslands. J. Mt. Sci. 16:2126-35.

Ponzetta MP, Cervasio F, Crocetti C, Messeri A, Argenti G, 2010. Habitat improvements with wildlife purposes in a grazed area on the Apennine mountains. Ital. J. Agron. 5:233-8.

Pornaro C, Basso E, Macolino S, 2019. Pasture botanical composition and forage quality at farm scale: A case study. Ital. J. Agron. 14:214-21.

Primi R, Filibeck G, Amici A, Bückle C, Cancellieri L, Di Filippo A, Gentile C, Guglielmino A, Latini R, Mancini LD, Mensing SA, Rossi CM, Rossini F, Scoppola A, Sulli C, Venanzi R, Ronchi B, Piovesan G, 2016. From Landsat to leafhoppers: a multidisciplinary approach for sustainable stocking assessment and ecological monitoring in mountain grasslands. Agric. Ecosyst. Environ. 234:118-33.

Probo M, Massolo A, Lonati M, Bailey DW, Gorlier A, Maurino L, Lombardi G, 2013. Use of mineral mix supplements to modify the grazing patterns by cattle for the restoration of sub-alpine and alpine shrub-encroached grasslands. Rangeland J. 35:85-93.

Rodríguez-Ortega T, Oteros-Rozas E, Ripoll-Bosch R, Tichit M, Martín-López B, Bernués A, 2014. Applying the ecosystem services framework to pasture-based livestock farming systems in Europe. Animal 8:1361-72.

Rojas-Downing MM, Nejadhashemi AP, Harrigan T, Woznicki SA, 2017. Climate change and livestock: Impacts, adaptation, and mitigation. Clim. Risk Manag. 16:145-63.

Rossignol N, Andueza D, Carrere P, Cruz P, Duru M, Fiorelli JL, Michaud A, Plantureux S, Pottier E, Baumont R, 2014. Assessing population maturity of three perennial grass species: influence of phenology and tiller demography along latitudinal and altitudinal gradients. Grass Forage Sci. 69:534-48.

Sabatini S, Argenti G, Staglianò N, Targetti S, 2008. Caratterizzazione delle risorse pascolive in un'area delle Alpi orientali in relazione ad alcuni parametri ecologici e gestionali. Forest@5:39-46.

Scotton M, Sicher L, Kasal A, 2014. Semi-natural grasslands of the Non Valley (Eastern Italian Alps): Agronomic and environmental value of traditional and new Alpine hay-meadow types. Agric. Ecosys. Environ. 197:243-54.

Skarpe C, Hester A, 2008. Plant traits, browsing and grazing herbivores, and vegetation dynamics. In: J. Gordon, H.H.T. Prins (Eds.), The ecology of browsing and grazing. Ecol. Studies 195:217-61.

Targetti S, Staglianò N, Messeri A, Argenti G, 2010. A state-andtransition approach to alpine grasslands under abandonment. iForest 3:44-51.

Targetti S, Messeri A, Staglianò N, Argenti G, 2013. Leaf functional traits for the assessment of succession following management in semi-natural grasslands: a case study in the North Apennines, Italy. Appl. Veg. Sci. 16:325-32.

Tasser E, Walde J, Tappeiner U, Teutschc A, Noggler W, 2007. Land-use changes and natural reforestation in the Eastern Central Alps. Agric. Ecosyst. Environ. 118:115-29.

Urbina I, Grau O, Sardans J, Ninot JM, Peñuelas J, 2020. Encroachment of shrubs into subalpine grasslands in the Pyrenees changes the plant-soil stoichiometry spectrum. Plant Soil 448:37-53.

Van den Pol-van Dasselaar A, Vellinga TV, Johansen A, Kennedy E, 2008. To graze or not to graze, that's the question. Proc. $22^{\text {nd }}$ Gen. Meet. European Grassland Federation, Uppsala, Sweden, 13:706-16.

Velev NI, Apostolova II, 2008. Successional changes of Nardus stricta communities in the Central Balkan Range (Bulgaria). Phytol. Balcan. 14:75-84.

Ziliotto U (coordinator), Andrich O, Lasen C, Ramanzin M, 2004. Tratti essenziali della tipologia veneta dei pascoli di monte e dintorni. Regione Veneto, Accademia Italiana di Scienze Forestali, Venezia, Italy. 